\title{
ADOLESCENTS' AWARENESS OF VARIOUS WAYS OF HUMAN TRAFFICKING AND PREVENTIVE STRATEGIES AS EXPRESSED BY SECONDARY SCHOOL STUDENTS IN OYO METROPOLIS
}

\author{
SHITTU, JOHN IDOWU (PhD); OYEDIRAN, AYOTUNDE OYEDELE (PhD) AND \\ OYELADE OYEKOLA OLUKAYODE (PhD)
}

\begin{abstract}
This study investigated adolescents' awareness of the various ways of human trafficking and preventive strategies among secondary school students in Oyo metropolis. Two research questions and two hypotheses were raised to guide the study. Descriptive survey method was adopted to carry out the study. Stratified random sampling technique was employed to select 250 respondents for the study. A researcher designed questionnaire titled 'Knowledge of Human Trafficking and Preventive Strategies Questionnaire' (KOHTPSQ); was used as instrument for data collection. The research questions were answered using mean, while the research hypotheses were tested using the z-test statistics at 0.05 level of confidence. The findings showed that male and female students of secondary schools in Oyo metropolis are to a great extent, aware of the ways by which human can be trafficked. A significant difference existed in the knowledge of the ways by which human are being trafficked. It was recommended that counsellors should organise group counselling session/workshop/seminar/ conferences for adolescents' and parents to educate them on various ways human can be trafficked. Also, government should intensify effort on preventive strategies against human trafficking.
\end{abstract}

\section{Introduction}

Human trafficking is modern day slavery involving victims who are forced, coerced or defrauded into labour or sexual exploitation. Annually, about 50 million women and 12 million children and youths are involved and are trafficked across national borders (Ochukwu, 2012). These figures do not include millions who are trafficked within their own countries (Copeland, 2012). Human Right Watch (2001) defines human trafficking as trading in human beings and includes: "all acts related to the recruitments, transport, transfer, sale or purchase of human beings by force, fraud, deceit or other coercive tactics for the purpose of placing them into conditions of forced labour/slavery. According to Trafficking Victims Protection Act (TVPA, 2000), people are snared into trafficking by many means which include false promises regarding job opportunities and marriages in foreign countries to entrap victims.

The impacts of human trafficking are numerous and multi-dimensional. Tor-Anyiin (2012) reported economic regression, gross transmission of sexually transmitted diseases, deprivation of victims' human rights and freedom (e.t.c) as by p-products of trafikking. Thus, human trafficking affects all the sectors of the economy, covering education, health and industrial development. Human trafficking is a global health risk, and it fuels the growth of organized crime in any society across the globe. Human trafficking has devastating effects on 
individual victims who often suffer physical and emotional abuse, rape, hard labour, threats against self and family, psychosocial problems, indiscriminate contact of sexually transmitted diseases, passport theft, and even death. In reality, the effect of human trafficking goes beyond individual victims. It undermines the safety and security of all nations it touches.

Human are trafficked both within and across the country, depending on the operator and their network of connection's (Subhatra, 2008). For instance, a number of people are trafficked from one location to the other within the same country and some human are trafficked across the nations. Majority of people being trafficked across the country are those that usually seeking entry through illegal means (Adedibu, Ademola and Lamidi, 2008). They are people often being deceived by the promise of good jobs or opportunity for study at the point of destination through agents and brokers who arranged the travel.

There are various means of combating human trafficking all over the world. The United Nation (UN) convention against trans-national organised crime Article 3(a) belief that a serious measures should be taken against individual or group of people indulging in human trafficking and defined clearly the concept of human trafficking to include recruitment, transportation, harbouring of persons by means of threat or use of force or abduction by fraud or abused of power or position of vulnerability of giving or receiving of payment to achieve the consent of a person having control over another person, for the purpose of exploitation. Trafficking impacts many nations, including the United State of America and Nigeria.

Based on the above, a number of measures have been taken to address issue of human trafficking. America further efforts to combat human trafficking include the following: Congressed Passed Legislation: That any Americans who sexually prey on children abroad can be prosecuted and sentenced as many as 30years in prison (UNICEF, 1997). The department of justice had focused on increasing the number of trafficking victims rescued and the number of prosecutions and convictions of traffickers. The Department of Health and Human Services (HHS) is certifying trafficked victims so that they may be qualify for necessary assistance that available for refugees. HHS is also running a major public awareness campaign to alert victims in the US that help is available through the hotline number 888.3737.888. The Department of Defence has implemented a zero-tolerance stand against any actions by defence personnel that contribute to human trafficking and is instituting a service-wide mandatory training programme (Copeland, 1995). The Department of Labour and Homeland Security, USAID, and other government agencies are executing action plans to combat human trafficking.

The report of Bureau of Public Affair (2004) has revealed that women and children are the most victims of human trafficking. One would find out that the affected populace is more among people within the productive age that are the bedrock of the economy and the future leaders. There is urgent need for all concerned with the survival and upliftment of the human race to put all hands on deck to ensure that those individuals who are vulnerable to this plague are well groomed on the strategies for the prevention of human trafficking. The concern of this paper, therefore, was to find out how much do secondary school students in Oyo metropolis of Oyo State in Nigeria know about the modalities of human trafficking and preventive measures against its further occurrence. 
The following research questions guided the study:

1. To what extent are students of secondary schools in Oyo metropolis aware of modalities of human trafficking?

2. To what extent do secondary school students in Oyo metropolis have necessary knowledge of measures that can prevent them from being victims of human trafficking?

These two research hypotheses were tested at 0.05 level of confidence:

1. There is no significant difference in the knowledge acquired by male and female of secondary school students in Oyo metropolis on the mode of human trafficking.

2. There is no significant difference in the knowledge of measures acquired by male and female secondary school students in Oyo metropolis that can prevent them from falling victims of human trafficking.

\section{Methodology}

Survey research design was employed for the study. The population consisted of all secondary school students in Oyo metropolis of Oyo State. The proportional stratified sampling technique was employed to select the sample for the study. The method was adopted to ensure a fair representation of groups in the variables used for the study. The proportional stratified sampling technique was preferred because it has a considerable gain over other techniques when the stratification is related to the variables of the study (Hassan, 1995). The stratification was based on the variables of the strata of the variable of gender that was studied. Thereafter, the simple random sampling technique was used to select 250 students for the study. A self- constructed instrument comprising 20 items was used for the study. 250 copies of the questionnaire were distributed to the respondents but a total of 233 were retrieved and used for data analysis.

Cronbach alpha method of establishing reliability of an instrument was used to analyse the data collected and coefficient of .88 was obtained for Cluster A, .78 for Cluster B, .9 for Cluster $\mathrm{C}$ while that of the entire instrument was .82. Four point Likert scale was used and each respondent indicated his/her level of agreement about the statements. The validity of the instrument was done by given it out to three experts in educational guidance and counselling and r.o experts in educational measurement and evaluation for both content and construct validation. Based on their comments, some items were modified while some were removed, and based on their judgment the instrument was adjudged good enough to conduct the study. The data obtained were analysed with the use of mean and standard deviation for the research questions, while the research hypotheses were tested using the z-test statistic at 0.05 level of confidence. 
Table 1: $\quad$ Mean rating and z-test result of knowledge acquired by male and female secondary school students on mode of human trafficking.

\begin{tabular}{|c|c|c|c|c|c|c|c|c|c|}
\hline $\begin{array}{c}\text { Items } \\
\text { No. }\end{array}$ & $\begin{array}{l}\text { Mode of Human } \\
\text { Trafficking }\end{array}$ & $\begin{array}{c}\text { A } \\
\text { Male } \\
\mathrm{N}=82 \\
\mathbf{x l}\end{array}$ & $\begin{array}{c}\text { B } \\
\text { Fem } \\
\text { ale } N \\
=151 \\
\text { SD1 }\end{array}$ & $\mathbf{X}^{2}$ & $\mathrm{SD}^{2}$ & $\begin{array}{c}\mathrm{C} \\
\mathrm{z} \text {-cal }\end{array}$ & & \multicolumn{2}{|c|}{ Discussion } \\
\hline 1. & The use of physical force & 1.72 & 0.96 & 2.09 & 0.98 & -2.51 & LE & GE & $\mathrm{S}$ \\
\hline 2. & $\begin{array}{l}\text { False promises by the } \\
\text { traffickers for better } \\
\text { marriage contract }\end{array}$ & 3.37 & 0.49 & 3.00 & 0.00 & 9.29 & VGE & GE & $\mathrm{S}$ \\
\hline 3. & $\begin{array}{l}\text { Promise of lucrative job in } \\
\text { the foreign country }\end{array}$ & 3.27 & 0.56 & 2.58 & 0.32 & 9.29 & VGE & GE & $\mathrm{S}$ \\
\hline 4. & $\begin{array}{l}\text { Enticing the person with } \\
\text { better and standard } \\
\text { education }\end{array}$ & 22.37 & 0.49 & 1.23 & 0.42 & 18.54 & GE & LE & $S$ \\
\hline 5. & $\begin{array}{l}\text { Entice the person for food } \\
\text { security perpetually }\end{array}$ & 1.72 & 0.96 & 2.09 & 0.98 & -2.51 & LE & GE & $\mathrm{S}$ \\
\hline 6. & $\begin{array}{l}\text { Luring them for good } \\
\text { standard of living without } \\
\text { any cost }\end{array}$ & 1.37 & 0.45 & 1.00 & 0.00 & 9.29 & LE & VLE & $\mathrm{S}$ \\
\hline 7. & $\begin{array}{l}\text { False promise of good } \\
\text { medical care for the rest } \\
\text { of their life }\end{array}$ & 1.72 & 0.69 & 1.61 & 0.71 & 1.04 & LE & LE & NS \\
\hline 8. & $\begin{array}{l}\text { Promise of special } \\
\text { treatment to refugee } \\
\text { without any cost }\end{array}$ & 3.87 & 0.35 & 3.87 & 0.34 & -0.80 & EVG & $\begin{array}{l}\text { VG } \\
\mathrm{E}\end{array}$ & NS \\
\hline 9. & $\begin{array}{l}\text { False impression of } \\
\text { lawlessness in foreign } \\
\text { country irrespective of } \\
\text { crime committed }\end{array}$ & 3.54 & 0.37 & 3.88 & 0.33 & -0.75 & VGE & $\begin{array}{l}\text { VG } \\
\mathrm{E}\end{array}$ & NS \\
\hline 10. & $\begin{array}{l}\text { Exhibiting audio-visual } \\
\text { tape that are captivating to } \\
\text { lure someone to place } \\
\text { being watched on the film } \\
\text { show }\end{array}$ & 3.53 & 0.63 & 1.77 & 0.81 & 11.43 & VGE & LE & $\mathrm{S}$ \\
\hline 11. & $\begin{array}{l}\text { Engaging in conversation } \\
\text { to know the interest of } \\
\text { someone and take the } \\
\text { advantage to lure the } \\
\text { person }\end{array}$ & 3.37 & 0.49 & 3.00 & 0.00 & 9.29 & VGE & GE & $\mathrm{S}$ \\
\hline 12. & $\mathrm{~N}=233$ overall & 2.72 & 0.55 & 2.36 & 0.36 & 6.11 & GE & GE & $\begin{array}{l}\mathrm{S} \text { reject } \\
\mathrm{H}_{0}\end{array}$ \\
\hline
\end{tabular}

- $\quad$ Significant at 0.05

\section{Discussion}

Male and female students of secondary schools in Oyo metropolis are to a great extent aware of the ways of which human beings can be trafficked. A significant difference was found in the mean scores of male and female students on their knowledge of the modalities for human trafficking as the calculated z-value at 0.05 level of confidence indicated. This is because the 
calculated $\mathrm{z}$-value (6. 11) is higher than the table $\mathrm{z}$ - value $(+1.96)$ at 0.05 level of significance. Thus, the null hypothesis of no significant difference is not accepted.

Due to positive response, the result revealed that gender has a strong influence on secondary school students' knowledge on ways by which human trafficking is taking place. This buttresses Copeland (2012) assertion that gender possibly aids reasoning and wisdom in human trafficking related issues. It probably confirms (Adedibu, Ademola and Laimidi, 2008) that the importance of gender involvement as a victim of human trafficking should not be underrated in a multiethnic society.

Research Question 2: To what extent do the secondary school students in Oyo metropolis have the necessary knowledge of measures that can prevent them from falling victims of human trafficking?

Research Hypothesis: There is no significant difference in the knowledge of measure acquired by male and female students of secondary schools in Oyo metropolis which can prevent them from falling victim of human trafficking.

Table 2: $\quad$ Mean rating and z-test result of male and female students in secondary school on the measure necessary for the prevention of human trafficking

\begin{tabular}{|c|c|c|c|c|c|c|c|c|c|}
\hline $\begin{array}{l}\text { Items } \\
\text { No. }\end{array}$ & $\begin{array}{l}\text { Mode of Human } \\
\text { Trafficking }\end{array}$ & $\begin{array}{l}\text { A } \\
\text { Male } \\
\mathrm{N}=82 \\
\mathbf{x l}\end{array}$ & $\begin{array}{l}\text { B } \\
\text { Female } \\
\mathbf{N}= \\
151 \\
\text { SD1 }\end{array}$ & $\mathbf{X}^{2}$ & $\mathrm{SD}^{2}$ & $\begin{array}{l}\text { C } \\
\text { Z-cal }\end{array}$ & \multicolumn{3}{|c|}{ Discussion } \\
\hline 13. & $\begin{array}{l}\text { Human trafficking } \\
\text { needs to be included } \\
\text { into our school } \\
\text { curriculum }\end{array}$ & 3.36 & 0.61 & 2.83 & 0.75 & 5.62 & VGE & GE & S \\
\hline 14 & $\begin{array}{l}\text { Legislators should } \\
\text { pass strict law } \\
\text { against perpetrators } \\
\text { of human } \\
\text { trafficking }\end{array}$ & 3.87 & 0.35 & 3.87 & 0.34 & 0.80 & VGE & VGE & NS \\
\hline 15 & $\begin{array}{l}\text { Government should } \\
\text { create more job } \\
\text { opportunities }\end{array}$ & 2.50 & 6.68 & 1.50 & 0.61 & -8.25 & GE & LE & $\mathrm{S}$ \\
\hline 16 & $\begin{array}{l}\text { Public awareness } \\
\text { through mass media } \\
\text { should be raise } \\
\text { against human } \\
\text { trafficking }\end{array}$ & 1.16 & 0.37 & 1.12 & 0.33 & 0.75 & $\mathrm{LE}$ & LE & NS \\
\hline 17 & $\begin{array}{l}\text { Government should } \\
\text { take drastic steps } \\
\text { against our porous } \\
\text { borders }\end{array}$ & 3.84 & 0.37 & 3.88 & 0.33 & -0.75 & VGE & VGE & NS \\
\hline 18. & $\begin{array}{l}\text { Anti-human } \\
\text { trafficking } \\
\text { agencies should be } \\
\text { strengthened in our }\end{array}$ & 1.79 & 0.67 & 1.82 & 0.66 & -0.28 & $\mathrm{LE}$ & LE & NS \\
\hline
\end{tabular}




\begin{tabular}{|c|c|c|c|c|c|c|c|c|c|}
\hline & country & & & & & & & & \\
\hline 19. & $\begin{array}{l}\text { Child right act } \\
\text { should taken very } \\
\text { seriously to protect } \\
\text { children from any } \\
\text { form of abuse }\end{array}$ & 3.69 & 0.50 & 3.27 & 0.44 & 4.75 & VGE & VGE & $\mathrm{S}$ \\
\hline \multirow[t]{2}{*}{20.} & $\begin{array}{l}\text { Government should } \\
\text { set up child and } \\
\text { youth empowerment } \\
\text { programme in the } \\
\text { country. }\end{array}$ & 3.16 & 0.37 & 3.12 & 0.33 & 0.75 & GE & GE & NS \\
\hline & $\mathrm{N}=2.33$ Overall & 2.91 & 0.49 & 2.29 & 0.47 & -1.77 & GE & $\mathrm{GE}$ & $\begin{array}{c}\text { NS do } \\
\text { not } \\
\text { reject } \\
\mathrm{H}_{0}\end{array}$ \\
\hline
\end{tabular}

Table 2 indicated that male and female students of secondary schools in Oyo metropolis do not have sufficient knowledge of measure that can prevent them from falling victim of human trafficking. No significant difference was found in the mean scores of male and female students on the knowledge of measures acquired that can prevent them from falling prey to human traffickers. This is because the calculated $\mathrm{z}$ - value $(-1.77)$ is less than the table $\mathrm{z}$ - value (+1.96) at 0.05 level of significance. This means that the relationship between genders of secondary school students on the knowledge of the measure acquired that can prevent them from falling prey to the hands of human traffickers is not statistically significant. The results above corroborate with (Adedibu; Ademola and Lamidi, 2008) that no significant difference was found between male and female students of tertiary institutions in Oyo State on knowledge about human trafficking.

\section{Conclusion}

There is urgent need for all stakeholders to stand against human trafficking before it becomes an uncontrollable monster in our society like that of hard drug, HIV/AIDS, Ebola and other current challenges facing the whole human race. It is important to know that a person who is victim of human trafficking is forced, defrauded or coerced into labour or sexually exploited and it affects almost every aspects of the victim's life emotionally, physically and socially and will also affect their level of functioning. As a result, everyone needs to have adequate knowledge of how individual can protect him/herself from falling prey to human traffickers.

\section{Recommendations}

It is the position of this paper that counselors should avail students and their parents of all the necessary information and knowledge on human trafficking to prevent them falling prey to those who perpetuate this dastard act. Specifically, the counsellors should:

1. Organise group counselling sessions/workshops/seminars/conferences for students and their parents/guardians to educate them on human trafficking: how it can be prevented; and not allowed to continue; impacts of human trafficking on individual 
and the society at large, means of protection, source of help available for them, and how to care for the victims of human trafficking among others.

2. Inculcate in students and significant other relevant knowledge and skills on human trafficking prevention behaviours likes: self-awareness, assertiveness/decision making assertiveness to resist pressures to sex negotiation, skills to ensure safer deal and practical skills for seeking assistance from professionally trained counsellors. The counselor also has uphill tasks of encouraging the students to seek counselling and not to have inordinate ambition to make it quick in life, but to face patiently the reality of life.

3. Finally, the students should be given opportunity to discuss the reasons they should not fall prey to human traffickers and learn how to resist pressures from anybody that wants to entice them to be a victim of human trafficking.

\section{References}

Adedibu, M.B.; Ademola, A.E. and Lamidi, S.O. (2008). Knowledge and attitude of students in tertiary institutions towards human trafficking. A conference paper presented at the 32 Annual Conference of Counselling Association of Nigeria, held at Kwara State, August $18^{\text {th }}-21$ st, 2008.

Bureau of Public Affairs (2004). Washington, DC: PDF.

Copeland, S. J. (1995). School intervention programmes: An approach to preventing child abuse. New Jesey: Medicine. 92 (2): $104-106$.

Copeland, J.K. (2012). Two faces of intercountry adoption: The significant of the Indian adoption Scandals. LGW Review, 3 (5):403 - 493.

Hassan, T. (1995). Understanding research in education. Lagos: Merrifield Coy.

Ochukwu, C.O. (2012). Parenting adolescents towards smooth transition to adulthood. Contemporary issues and researches on women, 231242.

Subhatra, S.B. (2008). Link between the ability to detect and manage trafficked victims. Ndalas:

Eket Press.

Tor-Anyin, S.A and Adamu, Y.R. (2012). Human trafficking: a national security challenge in Nigeria. A paper presented at the 38th Annual Conference of Counselling Association of Nigeria, held at Obafemi Awolowo University, Ile-Ife, August, 19 - 22 , 2012.

Trafficking Victims Protection Action (2000). United State of America.

UNICEF (1997). The State of the World's Children Oxford: Oxford University Press. 